\title{
ASSÉDIO MORAL NA ADMINISTRAÇÃO PÚBLICA BRASILEIRA: DO FORMALISMO PARA A PERSPECTIVA SOCIOJURÍDICA
}

\author{
MORAL HARASSMENT IN BRAZILIAN PUBLIC ADMINISTRATION: FROM \\ FORMALISM TO A SOCIO-LEGAL PERSPECTIVE
}

\begin{abstract}
Leonel Pires Ohlweiler
Mestre e Doutor em Direito.

Pós-Doutor em Direito pela Universidade Federal de Santa Catarina.

Desembargador do TJRS.

Professor da Unilasalle-RS.

leonel.ohlweiler@unilasalle.edu.br
\end{abstract}

\begin{abstract}
Resumo: O presente artigo examina o tema do assédio moral na Administração Pública, sob a perspectiva sociojurídica, relacionando-o como disfunção administrativa. Alerta para os perigos do formalismo jurídico na compreensão do conceito de assédio moral e refere possibilidades da sociologia de Pierre Bourdieu para analisar as ações assediadoras no âmbito do Direito Administrativo. A partir de casos judicializados de assédio moral investiga as decisões para caracterizar a ação social desenvolvida por agentes públicos assediadores, destacando o perfil das vítimas e os poderes administrativos utilizados. A metodologia aplicada foi pesquisa bibliográfica e jurisprudencial. O estudo propõe mecanismos de prevenção voltados para aumentar a democratização dos campos burocráticos.
\end{abstract}

Palavras-Chave: Assédio Moral. Administração Pública. Campo Burocrático.

Abstract: The present article examines the theme of moral harassment in Public Administration, from a socio-legal perspective, relating it as an administrative dysfunction. It warns of the dangers of legal formalism in understanding the concept of moral harassment and refers to the possibilities of Pierre Bourdieu's sociology to analyze the harassing actions within the scope of Administrative Law. Based on judicialized cases of moral harassment, it investigates decisions to characterize the social action developed by harassing public agents, highlighting the profile of the victims and the administrative powers used. The applied methodology was bibliographic and jurisprudential research. The study proposes prevention mechanisms aimed at increasing the democratization of bureaucratic fields.

Keywords: Moral Harassment. Public Administration. Bureaucratic Field.

OHLWEILER, Leonel Pires. Assédio moral na administração pública brasileira: do formalismo para a perspectiva sociojurídica. Revista Thesis Juris - RTJ, São Paulo, v. 9, n. 1, p. 73-103, jan./jun. 2020. http://doi.org/10.5585/rtj.v9i1.16870. 


\section{Introdução}

A investigação realizada versa sobre tema de grande importância para a Administração Pública, o assédio moral praticado por agentes públicos, ações administrativas abusivas consistentes em atentados contra a dignidade, repetidas, mediante atos, gestos, palavras e outros comportamentos capazes de criar situação de dominação das vítimas assediadas. O fenômeno não é novo, existindo diversos estudos na área do Direito do Trabalho, mas tratando do assédio no âmbito de empresas privadas.

No entanto, cada vez mais o assédio moral manifesta-se no próprio interior do Estado, considerando diversas peculiaridades do campo burocrático, ambiente propício para comportamentos marcados pela violência simbólica. Muito embora o foco de tais ilícitos não se relacione de modo direto com a questão da produtividade, a análise aqui realizada não exclui tal possibilidade, indicando também o fato da disputa de poder e a competitividade pelo domínio do espaço administrativo, como ingredientes cruciais.

A recepção do tema pelo Direito Administrativo é relevante, e permite diversas possibilidades para a pesquisa sobre o assédio moral, contribuindo para a compreensão do processo de desenvolvimento de tal prática, possíveis sanções aos agentes assediadores, além do desenvolvimento de políticas de prevenção, a fim de evitar a exclusão da vítima do mundo do trabalho público.

A perspectiva adotada neste artigo destaca o assedio moral na Administração Pública como ação sociojurídica, vislumbrando-o como consequência das influências do mundo social e do modo de funcionamento do campo administrativo do Estado, com as especificidades do exercício do poder, como ação oriunda de um habitus, princípio gerador e estruturador de práticas, de patologias funcionais.

O objetivo do trabalho consiste em olhar o assédio por meio das lentes da sociologia de Pierre Bourdieu (BOURDIEU, 1989), teoria de base utilizada para dialogar com o Direito Administrativo, aplicando e enriquecendo o leque de perspectivas. A metodologia empregada foi pesquisa bibliográfica e jurisprudencial de casos julgados pelo Tribunal de Justiça do Estado do Rio Grande do Sul no período de seis anos, de 2013 a 2019.

Inicialmente, destaca-se o assédio moral como patologia, indicando a relevância da questão no universo da Administração Pública e de que modo autores como Max Weber (WEBER, 1982) e Robert Merton (MERTON, 1970), com questionamentos sobre a burocracia, contribuem para discutir o tema da pesquisa. Na segunda parte do estudo individualizar-se-á o conceito de assédio moral, com a inicial teorização na área da psicologia, migrando para o 
Direito do Trabalho, até chegar ao Direito Administrativo, mas com a dimensão crítica de Pierre Bourdieu (BOURDIEU, 1989) sobre a necessidade de ultrapassar a doxa burocrática dos conceitos.

Após refletir sobre a normatização do assédio moral, discute-se com maior atenção o contributo do olhar sociojurídico, sendo que o debate sobre o habitus, campo e capital, indicadores empregados na pesquisa empírica, auxiliam na investigação do tema a partir do caráter relacional, ou seja, não é algo decorrente apenas de aspectos subjetivos, da intenção do agente assediador, bem como restrito à influência objetiva da estrutura.

$\mathrm{Na}$ última parte foram descritos os resultados da pesquisa empírica, focada em casos judicializados de assédio moral na Administração Pública, aplicando os indicadores do tópico anterior, permitindo compreender melhor o perfil dos agentes públicos assediadores, das vítimas assediadas e a prática do assédio nos espaços burocráticos.

As reflexões desenvolvidas integram o projeto maior desenvolvido no sentido de questionar as relações entre Administração Pública e Sociedade, cujo tema aqui tratado merece outros estudos, considerando as inúmeras possibilidades de pesquisa.

\section{Assédio Moral como Patologia do Mundo do Trabalho: a relevância do tema no espaço burocrático}

A incidência de casos de assédio moral na Administração Pública, cada vez mais, ocupa o cenário das preocupações com processos legítimos de gestão, deixando de caracterizar-se como fenômeno típico das organizações privadas. Conforme dados da Controladoria-Geral da União, cresceu o número das reclamações de maus-tratos praticados por superiores hierárquicos. No ano de 2015, a cada 62 (sessenta e duas) horas foram abertos procedimentos administrativos para apurar a prática de assédio moral, resultando na aplicação de sanções de demissão em relação a dois servidores públicos, quatro sanções disciplinares de advertência e duas destituições de cargos de provimento em comissão (TEMÓTEO, 2016). Para o fim de contextualizar a discussão que será realizada nesta investigação, a reportagem publicada descreve o caso de servidora pública do Ministério da Saúde relatando problemas com superiores desde o ano de 2002, consistentes em práticas vexatórias e de constrangimentos, além do isolamento da vítima de assédio moral em um cubículo, sem ventilação, com o propósito de apartá-la dos demais colegas da equipe de trabalho, vedando-se o compartilhamento de informações, cujo propósito comprovado de impedir o recebimento de tarefas. Em decorrência da prática, entrou em depressão e foi colocada à disposição do setor de Recursos Humanos sem maiores explicações. 
A servidora decidiu não somente levar o fato ao conhecimento da Ouvidoria-Geral da União (OGU), bem como encaminhar denúncia ao Ministério Público Federal (MPF), resultando na condenação dos dois superiores hierárquicos por atos de improbidade administrativa em face da prática de assédio moral. O caso não é isolado na Administração Pública Federal, segundo dados da CGU, entre os anos de 2015 e 2016 houve crescimento no número de processos administrativos instaurados para apurar denúncias de assédio moral, sendo que o número de apurações cresceu 51,1\% em 2015, ensejando 136 casos. Entre os meses de janeiro e setembro de 2016, conforme os mencionados dados, 118 processos administrativos foram instaurados, indicando uma média de um caso a cada 55 horas, cujos resultados foram aplicação de quatro sanções de advertência, três suspensões de servidores públicos e uma multa (TEMÓTEO, 2016).

Muito embora não seja o foco da investigação, em relação aos empregados públicos da Administração Pública Federal, conforme informação do Tribunal Superior do Trabalho, em janeiro de 2016 ocorreram 74 novos registros de assédio moral, 116 em janeiro de 2017, alcançando o pico de 218 em novembro daquele ano. Já, relativamente aos titulares de cargo efetivo, os dados igualmente são relevantes, de acordo com estatísticas da CGU, em termos de processos, de $1^{\circ}$ de janeiro de 2014 até 11 de abril de 2019 houve 906 processos tratando do assédio, incluindo o assédio sexual, com a punição de 94 servidores (BATISTA, 2019).

O quadro acima retratado indica a abrangência do assédio moral, não apenas como fenômeno local, mas algo inserido no que Juan B. Lorenzo de Membiela destaca como decadência ideológica de valores, transformando o exercício de poder em abuso de hierarquia ou de qualquer poder de fato (LORENZO DE MEMBIELA, 2007), predispondo a disparada da violência no trabalho, caracterizando-se como epidemia. $\mathrm{O}$ assédio moral na Administração Pública, como alude o autor, relaciona-se com o próprio processo de dominação que se desenvolve no Estado como campo de poder: "Lo que descriebe no es ni más ni menos que la dominación del funcionário por la Administración Pública prescindiendo de su dimensión personal, de su dignidad" (LORENZO DE MEMBIELA, 2007, p. 43).

Não se pode olvidar, o ambiente propício dos espaços burocráticos para a ocorrência de assédio moral, compreendendo a burocracia com algumas das características desenvolvidas por Weber, como atividade ordenada por regulamentos, por leis ou normas administrativas, distribuída de forma fixa como deveres oficiais, estruturada no princípio da autoridade, conferindo ao agente administrativo a competência para dar as ordens necessárias à execução de tais deveres, delimitada por normas relacionadas com os meios de coerção para a realização 
metódica e contínua de tais deveres (WEBER, 1982), configurando-se assim o conceito de autoridade burocrática.

A prática do assédio moral surge a partir do exercício de determinados poderes administrativos, em especial o hierárquico e o disciplinar, cujos desvios colocam a vítima em situações vexatórias e de humilhação. É claro que a concepção burocrática, na sua própria gênese, forma-se com base em níveis e escalonamentos, possibilitando a interposição de recursos para a autoridade superior (WEBER, 1982). No entanto, em quadros de assédio moral, a previsão formal sucumbe diante dos contextos fáticos de imposição da autoridade burocrática. Trata-se de fenômeno capaz de ultrapassar as dimensões formais e racionais da organização e do seu modo de documentação escrita do exercício das prerrogativas.

Outro aspecto da burocracia e digna de nota reside na circunstância de atribuir-se funções administrativas de acordo com o princípio da especialização e considerações exclusivamente objetivas característica, por um lado, relacionada com a busca de maior eficiência da atuação burocrática, mas, por outro, o cumprimento objetivo determina ações “sem relação com pessoas" (WEBER, 1982, p. 250).

Quando plenamente desenvolvida, a burocracia também se coloca num sentido específico, sob o princípio do sine ira ac studio. Sua natureza específica, bem recebida pelo capitalismo, desenvolve-se mais perfeitamente enquanto a burocracia é desumanizada, na medida em que se consegue eliminar dos negócios oficiais o amor, o ódio, e todos os elementos pessoais, irracionais e emocionais que fogem ao cálculo. É essa a natureza específica da burocracia, louvada como sua virtude especial (WEBER, 1982).

O assédio moral que será aqui examinado configura-se de modo paradoxal, ao mesmo tempo a Administração Pública prima pelo tratamento isonômico nas relações externas com os cidadãos, bem como, no plano interno, da própria instituição, mas também enseja ações e omissões desconsiderando aspectos individuais e pessoais dos agentes públicos, vítimas de constrangimentos e violências cotidianas no ambiente do Estado, ressaltando a incapacidade do sistema burocrático de lidar com tais situações de vulnerabilidade e personalizadas.

De algum modo, o assédio moral na Administração Pública relaciona-se com as denominadas disfunções da burocracia, para utilizar a expressão de Robert Merton (MERTON, 1970), mas que podem ser compreendidas como patologias burocráticas, fenômenos muitas vezes não alcançados pela racionalidade formal das regras da organização pública, capazes de ensejar desde o descumprimento de objetivos constitucionalmente legítimos da Administração, bem como a degradação da saúde dos agentes. O sociólogo parte do pressuposto de sua teoria funcionalista para compreender as disfunções, pois vislumbra a burocracia como espaço de 
organização formal, com divisão nítida de atividades integradas, consideradas como deveres inerentes ao cargo.

Algumas das características da burocracia, conforme o autor:

\begin{abstract}
Um sistema de controles e sanções diferenciados é definido nos regulamentos. A designação dos encargos ocorre na base das qualificações técnicas que são determinadas através de procedimentos formalizados e impessoais (por exemplo, exames). Dentro da estrutura da autoridade hierarquicamente disposta, as atividades dos 'peritos treinados e assalariados' são governadas por regras gerais, abstratas e claramente definidas, as quais evitam a necessidade de serem emitidas instruções específicas para cada caso particular (MERTON, 1970, p. 272).
\end{abstract}

Considerando tal estrutura social surgem as denominadas disfunções, com papeis relevantes para proporcionar riscos relacionados com o tema desta pesquisa. O espaço da Administração Pública é marcado pela pressão sobre o agente público, cujas causas são diversas. Para Robert Merton, a estrutura burocrática exerce uma pressão constante sobre o agente público, com a finalidade de adotar condutas metódicas, prudentes e disciplinadas para alcançar bons resultados (MERTON, 1970).

É claro, tais referências devem ser especificadas em termos da Administração brasileira, mas não se pode olvidar a falta de efetividade das autoridades responsáveis pela disciplina na Administração Pública para detectar, diagnosticar e encontrar soluções, considerando o "virtuose burocrático" (MERTON, 1970, p. 276), ao mesmo tempo, determina a incapacidade de ajudar não somente os cidadãos, mas os próprios agentes públicos vítimas de assédio moral.

Consoante já destacado anteriormente, quando o servidor enredado em situações de vulnerabilidade adquire coragem para reclamar, os arranjos institucionais da esfera burocrática, em alguns casos, tendem a dar pouca importância e até mesmo anular qualquer possibilidade de irresignação, tudo direcionado para preservar o espírito de corpo, ou seja, uma espécie de “organização informal que se desenvolve tipicamente em tais situações, frequentemente leva o pessoal a defender seus interesses arraigados" (MERTON, 1970, p. 277), desqualificando aquela vítima que pretende contextualizar modos e maneiras do fazer administrativo impregnado em determinados órgãos públicos.

E por fim, talvez uma das disfunções mais destacadas, resultado da norma de impessoalidade, a despersonalização das relações, também já detectado antes com base na concepção clássica de burocracia de Max Weber. Como alude Robert Merton, o conjunto de regras gerais e abstratas produz o resultado de o agente público reduzir o papel das relações pessoais, o que é benéfico em termos estruturais, mas produz a incapacidade de lidar com casos individuais, recorrendo com frequência aos tradicionais processos de categorização, pode-se 
dizer, não somente dos cidadãos de modo geral, como dos próprios agentes da Administração Pública. Logo, "o comportamento estereotipado não é adaptado às exigências dos problemas individuais" (MERTON, 1970, p. 279).

Tais referências das disfunções burocráticas, compreendidas como verdadeiras patologias, situam-se no horizonte do paradigma funcionalista moderado do autor, no qual a sociedade caracteriza-se como um sistema complexo, cujas várias partes atuam juntas para produzir estabilidade e solidariedade (GIDDENS, 2012), postura teórica voltada com maior ênfase nos consensos produzidos e determinados espaços sociais. No caso da burocracia, a ordem e o equilíbrio estariam de acordo com o estado natural das coisas. No entendimento de Giddens (2012, p. 31), “procurar os aspectos disfuncionais do comportamento social significa concentrar-se em aspectos da vida social que desafiam a ordem de coisas existentes". De qualquer modo, com o prisma de outras perspectivas sociológicas, e com maior riqueza de possibilidades, é crível vislumbrar o assédio moral na Administração Pública corolário do próprio campo de poder e estruturas de dominação presentes. A organização burocrática fundada em ordens, hierarquias e disciplina, produz poder, desigualdades e lutas constantes, engendrando espaços de tensão e relações de controle voltadas para o condicionamento de ações individuais, práticas de dominação simbólica.

\section{O Conceito de Assédio Moral no Direito (Administrativo): os perigos do formalismo jurídico}

O assédio moral foi objeto de investigações na área da psicologia e migrou para o Direito em virtude das repercussões óbvias nas relações jurídicas, em um primeiro momento, com maior visibilidade no âmbito do Direito do Trabalho. No entendimento de Maria Regina Redinha, assédio moral caracteriza-se como perseguição "metodicamente organizada, temporalmente prolongada, dirigida normalmente contra um só trabalhador que, por consequência, se vê remetido para uma situação indefesa e desesperada, violentado e frequentemente constrangido a abandonar o seu emprego, seja por iniciativa própria ou não". (REDINHA, 2003, p. 834).

Constatam-se indicações importantes e que foram bem compreendidas no âmbito do Direito do Trabalho, como tratar-se de autêntico ato de perseguição. Relacionando com a perspectiva adotada, é nítido o caráter de ação de dominação realizada pelo assediador. A prática assediadora nas relações de trabalho não ocorre ao acaso, mas se situa em contextos estratégicos, resultado, como menciona a autora, de uma organização, impondo-se destacar 
também a questão da duração temporal e do processo de dominação da vítima, muitas vezes excluída do mundo do trabalho.

Na mesma linha, Sonia Mascaro Nascimento refere o assédio moral como:

[...] uma conduta abusiva, de natureza psicológica, que atenta contra a dignidade psíquica, de forma repetitiva e prolongada, e que expõe o trabalhador a situações humilhantes e constrangedoras, capazes de causar ofensa à personalidade, à dignidade ou à integridade psíquica, e que tenha por efeito excluir a posição do empregado no emprego ou deteriorar o ambiente de trabalho, durante a jornada de trabalho e no exercício de suas funções (NASCIMENTO, 2004, p. 922).

Destaca-se de tal ideia o aspecto abusivo presente na relação de trabalho quando caracterizado o assédio moral, cujas diversas consequências nefastas expõem o trabalhador a situações humilhantes e constrangedoras (FURLAN; ALMEIDA, 2017), ofendendo a personalidade, a dignidade ou a integridade psíquica, de acordo com a autora.

Até pelas próprias condições epistemológicas de proteção ao trabalhador, o assédio moral foi construído para estabelecer alguns critérios de cuidado e também diferenciar de outras práticas que ocorrem nas relações trabalhistas. É relevante não perder de vista tal contexto quando se trata de igual fenômeno, mas na órbita das relações com a Administração Pública. Em texto no qual aborda a questão, Antonio Cogliandro parte do pressuposto da violência psicológica, para ele o assédio moral relaciona-se com diversas formas de violências psicológicas exercidas nos confrontos laborais, materializando-se como ação vexatória motivada por inveja, competição, antipatia, racismo, diversidades religiosa e cultural (COGLIANDRO, 2015).

Atendendo as indicações supra, é possível destacar a relação entre o tema e a existência de violência psicológica contra a vítima, além da presença relevante das questões sobre a caracterização de atos de perseguição e práticas vexatórias, mencionando-se, ainda, alguns dos motivos capazes de ensejar o assédio moral. Esther Gómez Jimènez alude que a Organização Internacional do Trabalho já definiu o assédio moral como "la acción verbal o psicológica de índole sistemática, repetida o persistente por la que, en el lugar de trabajo o en conexión con el trabajo, una persona o un grupo de personas hiere a una víctima, la humilla, ofende o amedrenta" (OIT apud GÓMEZ JIMÉNEZ, 2017, p. 251).

Os autores com pesquisas direcionadas para o mobbing na Administração Pública identificam tal campo como propício para ações assediadoras, nos termos expostos por Arenas (2013, p. 69): 
O serviço público propicia assédio moral devido ao grande número de pessoas empregadas, os servidores que para se diferenciarem no meio dessa grande massa, começam a assediar seus subordinados, ou mesmo uma repartição inteira. Como o serviço público está voltado para o bem público, dentro de um esquema social, os abusos chamam a atenção. $\mathrm{O}$ assédio não está relacionado à produtividade, como no setor privado, mas, muitas vezes, à disputa pelo poder, à inveja e à cobiça.

Quando se examina o tema do assédio moral no âmbito do Direito Administrativo devese atentar para os perigos da juridicização. As observações de Pierre Bourdieu sobre a ciência jurídica, o formalismo e o instrumentalismo são pertinentes para o debate. $\mathrm{O}$ primeiro ponto configura-se como a capacidade de afirmar a "autonomia absoluta da forma jurídica em relação ao mundo social, e do instrumentalismo que concebe o direito como um reflexo ou um utensílio ao serviço dos dominantes". Os questionamentos aqui realizados desvinculam-se dos pressupostos epistemológicos que vislumbram o Direito Administrativo como sistema fechado e autônomo, "cujo desenvolvimento só pode ser compreendido segundo a sua dinâmica interna" (BOURDIEU, 1989, p. 209).

As questões levantadas neste breve estudo partem da necessidade de discutir o assédio moral não somente sob a perspectiva do Direito Administrativo, mas de modo relacional com o mundo social, com os diversos contextos das vítimas, dos assediadores e da própria lógica do campo burocrático. A leitura da normatividade administrativa não pode cair no formalismo racionalizante desconhecendo que o próprio critério para significar a ação abusiva praticada resulta de condicionantes sociais e possibilidades de construção e funcionamento do espaço jurídico-administrativo.

Trata-se da necessidade de ultrapassar a doxa burocrática dos conceitos administrativos, quer dizer, o conjunto de pressupostos tidos como evidentes por si, fora de qualquer discussão, já que constituem "a condição tácita da discussão" (BOURDIEU, 1994, p. 123). Laborar com o assédio moral exige certa dose de heterodoxia para denunciar os processos simbólicos oficialmente institucionalizados no Estado, responsáveis por diversas formas de censura de sentido, mas que fazem parte do próprio modo de funcionamento deste campo. Constitui-se espécie de vigilância epistemológica com relação à juridicização do assédio moral pelo Direito (Administrativo), uma vez que a tendência é trazer para o campo científico a parcela do mundo social que caiba e confirme o discutido e formalizado pelos doxósofos, ou então, realizar leituras muito específicas daquilo que acontece no campo burocrático, a fim de não gerar maiores rupturas.

Aqui reside outro ponto relevante para o debate, a Administração Pública (o Estado) pensa o assédio moral a partir da lógica do campo de poder, pois tal ação ocorre no espaço normativo e estruturado do ente público, impondo-se atentar para leituras fundadas na doxa 
institucionalizada pelo seu específico modo de organização e daquelas regras de funcionamento que prevalecem em tal espaço burocrático.

No intuito de construir sentidos institucionalizados, os agentes públicos utilizam-se da linguagem oficial do Estado. Ademais, o ato de nomeação no que tange ao tema desta investigação, o assédio moral na Administração Pública, não se caracteriza como mero ato de linguagem, simples relação de troca linguística, mas também é relação de poder simbólico, atualizando-se relações de força que ocorrem dentro e fora do campo burocrático da Administração. Trata-se de elemento importante, ultrapassando a dimensão formal do juridicamente preponderante. $\mathrm{O}$ assédio na Administração exige destacar as condições sociais de produção. Não adianta somente procurar no texto, por óbvio que o texto é relevante, é importante assentar aquilo que "está inscrito nas relações sociais" e determina o modo de funcionamento dos textos no próprio campo jurídico (BOURDIEU, 1996, p. 24).

Atribuir sentido ao assédio moral na Administração Pública como tal, envolve diversos atos de dizer como as coisas são, em especial aqueles que ocorrem no interior do próprio Estado. Na linha do defendido por Bourdieu, são atos de nomeação ou de instituição, dotados de eficácia simbólica, considerando representar "a forma por excelência da palavra autorizada, palavra pública, oficial, enunciada em nome de todos e perante todos [...]” (BOURDIEU, 1989, p. 236). Neste tópico é sempre importante atentar não cair nos formalismos modelatórios dos atos de categorização do Direito Administrativo e tornar como espécie de nada social, algo sem importância, os aspectos fundamentais das ações assediadoras praticadas por agentes públicos.

A pesquisa com a perspectiva sociojurídica lida não somente com a construção de um conceito como ato de nomeação, enunciação, mas com as condições sociais de compreensão do assédio moral pelo campo de poder da Administração Pública e as condições de possibilidade do funcionamento interno, das relações entre os agentes do campo, dos interesses e capitais envolvidos, questionando os efeitos quase mágicos da eficácia simbólica da linguagem oficial sobre a questão, sob pena de cair e aceitar a categorização (BOURDIEU, 1989) jurídicoadministrativa.

Vale pontuar que o campo burocrático da Administração não é um mundo apartado do próprio mundo social e das relações de poder determinantes dos complexos modos de funcionamento, mas decorre de diversas estruturas estruturadas, historicamente construídas (BOURDIEU, 1989), valendo-se da condição de ente público para atomizar os atos simbólicos de nomeação, por exemplo, por intermédio de discursos abstratos, moldando ações praticadas por agentes públicos aos esquemas teóricos e práticos de funcionamento do campo. É indubitável a relação da tipificação legal de atos de assédio moral, mas não se pode cair na 
tentação ingênua da normatividade, considerando que a normatização é um ato simbólico de nomeação. O trabalho realizado por Bourdieu é de grande relevância para destacar tal dimensão da linguagem e do exercício dos poderes da Administração Pública, fruto de relações de disputas, seja no âmbito do próprio campo burocrático ou decorrente da interferência de capitais outros, como o econômico.

Dialogando com as premissas aludidas, o que significa compreender o assédio moral como ação sociojurídica para não se tornar refém do formalismo racionalizante?

Denota que assédio moral decorre das próprias influências do mundo social e do específico campo burocrático sobre o agente assediador, além de aspectos relacionados com a dimensão subjetiva do agente público e que, igualmente, repercute no modo de ser da Administração. O assédio moral que ocorre no campo da burocracia do Estado precisa ser problematizado considerando as condições de possibilidade da própria estrutura do ente público, além das influências relacionadas às dimensões do exercício do poder como prática (BOURDIEU, 1994) oriunda de um habitus. Com efeito, é relevante indagar sobre as condições de produção do assédio conectadas com o próprio modo de estruturação e funcionamento da Administração como campo de poder, com estruturas que tendem a ser reproduzidas e capazes de produzir efeitos simbólicos de constrangimento, humilhação, etc.

\section{Perspectivas Sociojurídicas do Assédio Moral: habitus, campo e capital}

O assédio moral na Administração Pública, considerado como prática, como ação sociojurídica, ocorre na órbita do uso abusivo de competências administrativas, resultado do habitus do agente público, sendo possível identificar alguns componentes do que se poderia denominar de habitus burocrático próprio, conjunto de disposições, do modo de agir no espaço administrativo - estado habitual, predisposições, tendências, propensões - marcadas por indiferença, dominação, patologias burocráticas em geral, discriminação, humilhação e abusividades, duráveis, estruturas estruturadas predispostas para reprodução de práticas e representações burocráticas sem ser produto de obediência a regras, na linha do entendimento de Pierre Bourdieu sobre o habitus (BOURDIEU, 1994).

O assédio moral na Administração Pública configura-se espécie de violência simbólica que ocorre no espaço institucional da burocracia do Estado, espaço esse também dividido por grupos e erigido a partir de múltiplas práticas típicas e capazes de identificar o grupo, como ações administrativas, atividades de poder, ritos burocráticos, modos de compreensão e do fazer público, linguagens oficiais, etc. A ação assediadora, sob a perspectiva sociojurídica, não é 
problematizada somente nas dimensões de subjetividade do assediador, ou da estrutura administrativa, mas exige a constante reflexão sobre as relações dialéticas entre sociação e individuação, resultado do conjunto dinâmico de disposições sobrepostas (WACQUANT, 2007), muitas vezes sem guardar coerência.

Um indicador importante para compreender a ação assediadora reside na discricionariedade. No exercício de tal competência administrativa possibilita-se considerável margem para a tomada de decisões, além da própria manipulação simbólica de sentidos normativos. Como sustenta Freitas (2013, p. 344):

[...] pode-se, assim, compreender a discricionariedade administrativa legítima como a competência administrativa (não mera faculdade) de avaliar, escolher, no plano concreto, as melhores consequências, mediante justificativas válidas, fática e juridicamente aceitáveis, observados os requisitos da efetividade do direito fundamental à boa administração pública ${ }^{1}$.

Valendo-se de prerrogativas marcadas por discricionariedade, agentes públicos incorrem em assédio moral quando, por exemplo, com ações burocráticas de ordenar e designar para realização de tarefas esvaziam as atribuições da vítima assediada, dotando o exercício da competência administrativa de aparente legitimidade, cuja análise aprofundada possibilita descortinar a violência simbólica de autêntico castigo. As prerrogativas públicas de ordenação e designação fazem parte do sistema de disposições predispostas para funcionarem como estrutura estruturante de representações de dominação, assumindo-se como modo de agir inerente à concepção de ação discricionária da autoridade burocrática.

Também integra o habitus burocrático no qual ocorre o assédio moral o sentido simbólico de interesse público. Como mencionava Lima (2007), a relação de administração é relação jurídica estruturada sob o influxo de uma finalidade cogente, cujas prerrogativas devem materializar o interesse público.

Constata-se em tal indicador o que Bourdieu (1989) menciona como poder simbólico presente no modo de exercício das atividades administrativas para a imposição e definição do próprio mundo social e do conjunto de regras do subcampo burocrático, ações essas direcionadas na verdade para acomodar interesses específicos de dominação sobre a vítima de assédio moral. O sentido de interesse público utilizado por agentes públicos assediadores possibilita compreender, em geral, a inicial submissão da vítima a tais ações. Não se trata de relação de força física, mas simbólica, contando com a invisibilidade do poder simbólico que

\footnotetext{
${ }^{1}$ A questão da discricionariedade administrativa é tratada em muitos artigos e obras específicas, como Binenbojm (2014), Di Pietro (2001), e Cassagne, (2016).
} 
cria instâncias de significação, impondo à vítima do assédio estruturas cognitivas ${ }^{2}$ como se realmente o sentido dado pelo assediador fosse capaz de indicar o verdadeiro interesse público e, por consequência, o cumprimento de ordens, a realização de determinada tarefa vexatória ou até submeter-se a específico estado de humilhação, tudo em nome do interesse público da qual é o portador oficial.

Aqui reside a dimensão simbólica do interesse público, visto que o agente responsável pela ação assediadora não somente produz, mas reproduz e impõe como agente autorizado pelo Estado princípios de divisão e classificação ${ }^{3}$, no quais a vítima assediada passa a integrar a espécie de agentes que não se enquadram no padrão normal e precisam ser ajustados por meio de ritos de instituição, como a materialização de ordens administrativas e outros mecanismos de seleção simbólica.

Em relação ao habitus do assédio na Administração, o processo de legitimação do sentido simbólico de interesse público conta com o discurso burocrático. A linguagem utilizada pelo agente público assediador, atuando em nome do Estado, é depositária da filosofia social que se deve recuperar. O dizer burocrático é forma especial de dizer as coisas, mas, e aqui reside o mecanismo utilizado, dizer de modo oficial no horizonte de funcionamento do espaço institucional do ente público (BOURDIEU, 2014a) ${ }^{4}$, nomeando e enunciando a vítima como alguém fora do padrão.

Após a descrição do habitus burocrático presente no assédio moral, cumpre localizá-lo no horizonte do campo administrativo. O Estado não é um bloco, mas um campo, setor particular do campo do poder, com agentes próprios e formas de capital específicas, além de interesses diversos, circunstância determinante para a existência de diferentes divisões de funções (BOURDIEU, 2014a) ${ }^{5}$.

Não é possível aqui reconstruir o processo de formação do Estado como campo burocrático, salientando-se apenas que o resultado das formas de organização da Administração brasileira foi marcado pela desorganização, com poucas exceções em casos pontuais de gestões

\footnotetext{
${ }^{2}$ Conforme Pierre Bourdieu, "os atos de submissão e de obediência são atos cognitivos que, como tais, empregam estruturas cognitivas, categorias de percepção, esquemas de percepção, princípios de visão e de divisão, todo um conjunto de coisas que a tradição kantiana põe em primeiro plano" (BOURDIEU, 2014a, p. 226).

${ }^{3}$ Para Pierre Bourdieu "O Estado está em estado (se posso dizer) de impor de maneira universal, na escala de certa instância territorial, princípios de visão e de divisão, formas simbólicas, princípios de classificação, o que costumo chamar de um nomos [...]." (BOURDIEU, 2014a, p. 228).

${ }^{4}$ No entendimento do sociólogo, "a forma é uma propriedade muito importante desse discurso, pois é através dela que o indizível, às vezes o inominável torna-se nominável; ela é o preço a pagar para tornar oficializável o que não podia ser nomeado" (BOURDIEU, 2014a, p. 98).

${ }^{5}$ Em geral, a Administração Pública é tomada em sentido subjetivo ou formal, para indicar as pessoas jurídicas, os órgãos e os agentes públicos, bem como em sentido material, destacando-se a própria atividade administrativa (OLIVEIRA, 2018, p. 39). O tema desta pesquisa adota a perspectiva da Administração Pública como campo de poder, cuja dimensão é mais de caráter relacional, do conjunto de relações entre agentes do campo.
} 
municipais e estaduais bem sucedidas, alimentado pela lógica de uma sociedade escravista, com agentes utilizando a violência simbólica para a imposição de poderes, forte traço de hierarquização, confundindo-se autoridade com posturas de humilhação e opressão ${ }^{6}$. Tais referências são suficientes para colocar o campo administrativo como propício para a ocorrência de casos de assédio moral.

Delimita-se o campo como espaço estruturado de posições, postos, no caso da Administração, cargos, cujas propriedades dependem das posições dos agentes nestes espaços, dotado de algumas leis de caráter geral no que diz respeito ao modo de funcionamento, marcado por lutas entre os novos integrantes e os dominantes, com ações voltadas para defender o monopólio e exclusão da concorrência. (BOURDIEU, 1983, p. 89). Vale a referência expressa de Pierre Bourdieu:

\footnotetext{
Um campo, e também o campo científico, se define entre outras coisas através da definição dos objetos de disputas e dos interesses específicos que são irredutíveis aos objetos de disputas e aos interesses próprios de outros campos (não se poderia motivar um filósofo com questões próprias dos geógrafos) e que não são percebidos por quem não foi formado para entrar neste campo [...]. Para que um campo funcione, é preciso que haja objetos de disputas e pessoas prontas a disputar o jogo, dotadas de habitus que impliquem no conhecimento e reconhecimento das leis imanentes do jogo, dos objetos de disputas, etc. (BOURDIEU, 1983, p. 89).
}

Situar o assédio moral na Administração Pública na concepção de campo administrativo permite compreendê-lo como ação sociojurídica, dotado de caráter relacional inicialmente por meio das posições ocupadas pelos agentes. No campo burocrático, a posição dos agentes depende do modo da organização hierárquica, pois a própria estrutura deste espaço é um estado de relações de força, de distribuição de capital, do monopólio da violência legítima, com estratégias construídas para a manutenção, conservação e defesa da ortodoxia. Em casos de assédio, ao menos entre agentes situados em contextos de hierarquização, o dominante utiliza suas prerrogativas públicas para dominar e significar, quer dizer, atribuir à ação o caráter de legítima manifestação de poderes.

No exercício da hierarquia é possível referir como ações materiais muitas vezes utilizadas como estratégias de dominação, as ameaças individualizadas a fim de minar o estado de ânimo da vítima assediada, emissão de ordens, com aparência de legítimo exercício de prerrogativas, mas que abarcam sentidos de impor humilhação, tratamento vexatório ou de discriminação, o que pode ocorrer com a determinação de permanecer durante períodos de tempo em determinado espaço ou falar com outros agentes públicos, a ação de impedir a vítima

\footnotetext{
${ }^{6}$ Sobre o tema da evolução da Administração Pública brasileira ver Torres (2004) e Nohara (2012).
} 
de realizar suas atividades funcionais e até a concessão de direitos de ofício, com o propósito de afastar o servidor (concessão de férias).

O campo administrativo é um espaço hierarquizado, estruturado de posições e tomadas de posições (WACQUANT, 2015), nos quais os agentes públicos que o integram, além de instituições públicas e privadas, competem pelo monopólio da autoridade administrativa no âmbito desta esfera relativamente autônoma em relação aos campos políticos, econômicos e sociais. É nota característica do assédio moral a posição de autoridade assumida pelo assediador, em especial naqueles casos de assédio vertical, direcionando suas ações de dominação para as vítimas assediadas, compreendendo-as não apenas no horizonte da hierarquia funcional, mas como pessoas que podem sofrer tratamentos vexatórios.

Não se pode olvidar, a partir da matriz teórica adotada neste breve estudo, o exercício da hierarquia administrativa envolve a imposição do princípio legítimo de dominação, caracterizada pela dimensão simbólica de legitimar um modus operandi, a espécie de capital em que repousa o poder do assediador. Considerando as estratégias materializadas no âmbito do campo de forças, pode-se configurar o fazer administrativo do assédio moral por meio de: a) ameaças, b) concessões, c) ordens, d) esvaziamento de atribuições, dentre outras.

Na primeira hipótese o assédio manifesta-se pela explicitação do poder de ameaça, de impor algo ruim ou vexatório para a vítima, mas, ao mesmo tempo, atuando na linha dúplice de benefícios e constrangimentos, considerando que a concessão de direitos de ofício representa não a atitude voltada para conceder direitos e sim explicitar quem manda na Administração municipal. Tudo isso aliado com o reforço de ordens e a situação de humilhação ao esvaziar as atribuições do cargo, direciona-se para desconstruir parte da dimensão simbólica que a vítima ocupa no campo administrativo. Já que não é possível retirá-la do cargo público ocupado, salvo pelos procedimentos formais, bem como impedir de exercer as funções próprias, adota-se a estratégia de criar situação de assédio, minando a força da vítima no espaço burocrático.

Para bem delimitar o modo de funcionamento do campo na prática do assédio moral na Administração, destaca-se a presença da disciplina administrativa. A disciplina integra os mecanismos de dominação do espaço de forças e de poder da burocracia, configurando-se como "o comportamento interno da Administração, no sentido formal e material, que, com a observância da forma, do objeto e do motivo previsto em lei, é concretizado pela autoridade 
competente", para aplicar uma sanção disciplinar ao subordinado faltoso, e velar pela regularidade e aperfeiçoamento do serviço público (COSTA, 2008, p. 22$)^{7}$.

No entanto, para os objetivos desta investigação, o mais relevante da disciplina administrativa reside no caráter relacional, as relações de poder simbólico (LIMA, 2010) envolvidas nas quais é exercida em contextos de assédio moral, traduzindo-se em oposição de forças, postando-se o assediador como detentor de poderes para dominar o campo administrativo. Imputando à organização do espaço da Administração o exercício das prerrogativas disciplinares, o assediador qualifica a vítima como subordinado faltoso e legitima-se por meio do argumento de concretizar os propósitos previstos em lei, direcionados para aperfeiçoar o serviço público. O caráter disciplinar da própria posição de autoridade no campo segue a lógica do Estado de classificação, distinção e universalização (BOURDIEU, 2014a), com a especificidade de ocorrer no âmbito interno da Administração.

A partir do estudo sobre assédio moral na Administração também é possível compreender os mecanismos de reprodução burocrática presentes na ação do assediador, tal prática não se restringe à percepção do assediador e da vítima. Como ação simbólica, precisa ser concretizada no espaço de outros agentes do campo administrativo em situações similares de relações hierárquicas múltiplas, funcionando para legitimar a dominação do assediador e assegurar a posição de autoridade conquistada. É outra estratégia do habitus burocrático relacionado com a ortodoxia, manutenção da ordem das coisas.

O campo administrativo configura-se a partir do conjunto de propriedades, dentre elas as múltiplas relações de forças entre os agentes. Aqueles situados como dominantes estão em permanente processo de luta para a defesa do monopólio do capital específico, no caso do espaço da Administração Pública, do capital administrativo ou burocrático. A ideia de capital foi utilizada por Bourdieu (2001) de modo diverso da significação econômica, na medida em que entendia tal conceito fundamental para dar conta da estrutura e funcionamento do mundo social, constituindo-se em força inerente às estruturas objetivas e subjetivas e, ao mesmo tempo, princípio fundamental das regularidades internas. No entendimento do sociólogo, em virtude da multiplicidade de campos no mundo social, há capitais com diferentes naturezas (SANTOS, 2019), econômico, social, cultural, político, etc., e que aparecem como recursos sociais para os agentes, ou melhor, "um estoque de volume mais ou menos importante, cada espécie de capital

\footnotetext{
${ }^{7}$ Para Sánchez Morón (2008, p. 299), a responsabilidade disciplinar diz respeito ao descumprimento de deveres funcionais por servidores públicos, cujas infrações possuem natureza administrativa, conforme a legislação vigente, regulação e regime jurídico próprio.
} 
é fruto de uma acumulação em vista de obter um proveito ou rendimento, material ou não" (JOURDAIN; NAULIN, 2017, p. 126).

Com o intuito de bem dimensionar o capital em jogo, adota-se nesta pesquisa o que se poderia denominar de capital funcional ou burocrático, específico do campo administrativo no qual o assédio moral ocorre. Para vislumbrar a complexidade do capital funcional, urge destacar as formas de capitais descritas por Bourdieu (2001), como o capital social, capital de obrigações e relações sociais, correspondendo ao conjunto de acessos sociais, relacionamentos e redes de contato (THIRY-CHERQUES, 2006) ${ }^{8}$; o capital econômico, aquele direta e imediatamente convertido em dinheiro ${ }^{9}$ e o capital cultural, referente aos recursos culturais dos quais o agente dispõe, podendo converter-se sob certas condições em capital econômico e resulta apropriado para a institucionalização, sobretudo, em forma de títulos acadêmicos ${ }^{10}$.

De acordo com Bourdieu (2004, p. 163), o denominado capital simbólico, relacionado com as ideias de prestígio e reconhecimento, caracterizado do seguinte modo: "não é outra coisa senão o capital econômico ou cultural quando conhecido e reconhecido, quando conhecido segundo as categorias de percepção que ele impõe, as relações de força tendem a reproduzir e reforçar as relações de força que constituem a estrutura do espaço social”.

O capital funcional assemelha-se ao capital simbólico, por agregar as dimensões do capital econômico, manifestado pelo próprio valor das remunerações no campo administrativo, ao capital cultural, considerando o conjunto de conhecimento do agente público, em especial o capital cultural institucionalizado, bem como ao capital social, formado pelo conjunto de relações mantidas no espaço da burocracia da Administração.

Em casos de assédio moral, seguindo a própria lógica do mundo social, identifica-se a presença de luta por reconhecimento, valendo-se o assediador para a manutenção do conjunto de capitais que possui, conforme as especificidades do campo administrativo. Destaca-se ainda, em tais contextos a necessidade de o agente público assediador lutar para o reconhecimento de autoridade do respectivo campo burocrático, valendo-se de diversas formas para alcançar tal

\footnotetext{
${ }^{8}$ Conforme Bourdieu (2001, p. 148) “o capital social está constituído pela totalidade dos recursos potenciais ou atuais associados à posse de uma rede duradora de relações mais ou menos institucionalizadas de conhecimento e reconhecimento mútuos. Expressado de outra forma, trata-se aqui da totalidade de recursos baseados na pertença a um grupo".

${ }^{9}$ Destacam Jourdain e Naulin $(2017$, p. 126) que o "capital econômico designa o conjunto de recursos econômicos de um indivíduo englobando tanto o seu patrimônio material quanto seus salários. $\mathrm{O}$ fato de dispor de capital econômico permite adquirir mais facilmente outros tipos de capitais".

10 Sobre o capital cultural, Thiry-Cherques (2006, p. 39) destaca abarcar "o conhecimento, as habilidades, as informações, etc., correspondente ao conjunto de qualificações intelectuais produzidas e transmitidas pela família, e pelas instituições escolares, sob três formas: o estado incorporado, como disposição durável do corpo (por exemplo, a forma de se apresentar em público); o estado objetivo, como a posse de bens culturais (por exemplo, a posse de obras de arte); estado institucionalizado, sancionado pelas instituições, como os títulos acadêmicos”.
} 
OHLWEILER, Leonel Pires. Assédio moral na administração pública brasileira: do formalismo para a perspectiva sociojurídica

desiderato, desde ameaças, até adoção de medidas administrativas legalmente previstas, mas utilizadas com desvio de finalidade.

O aludido capital funcional, que na verdade assume-se como capital simbólico, indica a situação de perversidade envolvida no assédio moral, uma vez que a ação do assediador direciona-se para, mediante práticas de dominação, criar situações vexatórias ou simplesmente ignorar a presença do servidor, valendo-se do exercício de competências administrativas com abuso de poder. Segundo menciona Hirigoyen (2014, p. 113), a comunicação perversa está presente no assédio, pois "a recusa do diálogo é um modo de dizer, sem expressá-lo diretamente em palavras, que o outro não lhe interessa".

\section{A Caracterização do Assédio Moral na Administração Pública: indicações a partir da pesquisa empírica}

Com o intuito de ilustrar a pesquisa, serão destacados neste tópico, alguns dados sobre a prática do assédio moral na Administração Pública de casos judicializados e examinados pelo Tribunal de Justiça do Estado do Rio Grande do Sul e Turmas Recursais da Fazenda Pública entre os anos de 2013 a 2019, período da investigação. O ano de 2013 foi um marco significativo, pois constatou-se um aumento significativo de feitos julgados ${ }^{11}$. No propósito de melhor delimitar a análise, a pesquisa restringiu-se às apelações e recursos inominados, descartando-se assim, o julgamento de outros feitos, como agravos de instrumento e embargos de declaração. Adotando tais parâmetros de restrição, o universo do material ficou restrito ao número de 44 (quarenta e quatro) acórdãos ${ }^{12}$. Com finalidade de qualificar a observação do corpus da investigação de caráter empírico, elaborou-se documento de análise com os principais dados das apelações e recursos inominados, indicações sobre o perfil das vítimas assediadas, os cargos públicos dos assediadores, os cargos ocupados pelas vítimas assediadas, os poderes administrativos exercidos para a prática do assédio moral, breve descrição das condutas assediadoras e as consequências do assédio para as vítimas.

\footnotetext{
${ }^{11}$ Ao consultar o site www.tjrs.com.br, pesquisa de jurisprudência, em 2011 aparecem apenas 11 apelações, cujo número progride em 2013: 23 casos julgados; 2014: 34 apelações; 2015: 47 apelações; 2016: 49 apelações; 2017: 46 apelações; 2018 com 56 apelos e 2019: 46 casos julgados pelo TJRS.

12 Acórdãos examinados: 70035025717,71004523973, 700476211131, 70060899937, 70062961958, 70038568937, 70059102756, 70065169690, 70061992020, 70063691414, 70060391430, 70061311494, 70065688798, 70061840856, 71005491808, 70068119841, 70067256917, 71006147516, 71005997051, 70070223862, 70064741291, 70069301430, 70073828378, 70076850155, 70076700376, 70070349030, 70076660521, 70075684019, 70078282191, 70063964332, 70079576724, 70057814170, 71007964430, 70076846211, 70082663857, 70073134215, 70076753391, 71008319162, 70080901473, 70079214326, 7007781607, 70081216236, 70083046110 e 70081304859 .
} 
É claro que outros diversos aspectos poderiam ser explorados, mas o propósito não é esgotar a questão e apenas iniciar o debate sobre a configuração do assédio moral na Administração Pública, dialogando com referências sociojurídicas de casos judicializados.

Como já discutido em relação ao denominado habitus burocrático, o assédio moral materializa-se por meio do exercício de determinadas competências administrativas, indicando a utilização abusiva de poderes direcionados para impor processos de dominação simbólica, resultado do estado habitual dos agentes assediadores, das tendências e propensões marcadas pela indiferença em relação às vítimas, além das ações de discriminação e humilhação.

A discricionariedade administrativa é importante indicador para compreender o modo da ação assediadora, tendo em conta a ampla margem de manipulação de sentidos e das prerrogativas públicas. Examinando o total das 44 (quarenta e quatro) decisões, detectou-se a presença de tal competência discricionária em $96,7 \%$ dos casos. A relação entre habitus e discricionariedade para o propósito da pesquisa sobre o assédio moral na Administração Pública é relevante, para compreender que a prática da ação assediadora não decorre do efeito mecânico de causas externas, nem é consequência exclusiva de ação racional conscientemente calculada, mas do habitus incorporado, do conjunto de disposições adquiridas, inclusive, no próprio campo burocrático (BOURDIEU, 2001a).

As ações assediadoras identificadas nos casos julgados pelo TJRS, alterações de turno de trabalho, remanejamento da vítima assediada, colocar o servidor à disposição, dentre outras, originaram-se do próprio modo de construção dos espaços de poder da Administração Pública, nos quais o exercício do poder administrativo distribuído assumiu a dimensão de subjugar, da legitimidade para desconsiderar o outro, no caso, a vítima assediada e, muitas vezes, em situação hierarquicamente inferior. Nos termos já mencionados, para Wacquant (2007) o habitus traduz uma dimensão social dependendo dos processos de distribuição de poder. É tão presente tal aspecto que em um dos acórdãos apareceu a prática do assédio em virtude de o assediador ordenar que a vítima assediada somente poderia exercer suas atividades de agente de trânsito e autuar motoristas com autorização expressa do assediador.

Conforme Bourdieu (1994, p. 61), as práticas produzidas pelo habitus "tendem a reproduzir as estruturas objetivas das quais elas são, em última análise, o produto", detectandose nos casos de assédio moral que integram o corpus desta breve pesquisa, o arbítrio no exercício dos poderes administrativos. Trata-se do modo de funcionamento dos diversos campos burocráticos por intermédio da figura da autoridade, valendo-se de suas funções para impor práticas perversas às vítimas. Colocar a vítima assediada à disposição, remoção de servidor para local diverso da prestação do serviço, valer-se do cargo para ameaçar servidores, 
denotam o modo de estruturação de algumas Administrações nas quais o agente assediador situa-se no espaço burocrático como alguém "dono do campo", autoridade dominadora dos agentes públicos.

O habitus, portanto, possibilita na linha da compreensão de Wacquant (2007, p. 68), destacar duas dimensões da prática do assédio moral na Administração Pública, a sociação e a individuação. Sob aspecto do espaço institucional do Estado é possível vislumbrar determinadas práticas e disposições partilhadas por um conjunto de agentes públicos assediadores, categorias decorrentes do modo de ser do campo administrativo (sociação), capazes de erigir um habitus burocrático. Todavia, não se pode olvidar as questões individuais do agente público assediador (individuação), como a dimensão de perversidade no modo de exercício das competências funcionais em relação à vítima, fruto da própria trajetória na sociedade e no âmbito do serviço público.

A questão da linguagem possui relação íntima com o exercício dos poderes administrativos e também compõe o habitus burocrático em contextos de assédio moral, o denominado sentido simbólico de interesse público. Nos termos já explicitados, não há dúvida, o interesse público constitui-se importante diretriz para a Administração Pública materializar os princípios do Estado Democrático de Direito. Não obstante, a manipulação simbólica está presente no quadro de assédio quando o assediador, valendo-se de prerrogativas funcionais, realiza ações direcionadas para acomodar interesses específicos de dominação sobre a vítima assediada, contando com a invisibilidade do poder simbólico.

Deve-se destacar que muitas vezes em casos de assédio moral ocorre a primazia do agente assediador, resultado da própria estrutura administrativa do Estado e do conjunto de atividades produtivas e reprodutivas (BOURDIEU, 2014b), inculcando no modo de funcionamento das relações funcionais princípios de divisão nos quais a hierarquização confere o sentido de legítima dominação sobre a vítima assediada.

Ao examinar o material utilizado na investigação verificou-se a presença do indicador poder simbólico em $81,8 \%$ dos acórdãos, atuando de modo quase invisível nas seguintes hipóteses: aplicação de advertência em nome da disciplina no serviço público; decisão administrativa sobre a lotação de servidor para melhor adequação de espaços, em nome da disciplina; a suspensão de servidor do exercício de suas atividades laborais, instauração de sindicância administrativa, bem como o exercício de competência administrativa para formar equipe em operações especiais, deixando a vítima assediada de fora. Outras utilizações de competências administrativas são dignas de nota, como a prerrogativa de organizar as escalas de serviço para melhor atender a eficiência, realizar atribuições diversas das previstas para o 
cargo público, considerando a necessidade do serviço, cobrar ações do agente público para o bom andamento do serviço, registrar advertência em atas de reuniões administrativas, retirar cargos de chefia e estagiários e troca de horário de serviço.

É claro que o processo de legitimação do sentido simbólico de interesse público, nas diversas ações acima referidas, contou com o discurso burocrático, outro elemento integrador do habitus do campo da Administração, concretizando-se por intermédio da linguagem empregada pelo agente assediador, atuando de modo oficial em nome do Estado, impondo o sentido da dominação nominada de interesse público, seja para aplicar sanções disciplinares ou concretizar atos rotineiros de gestão pública, mas sempre manipulando a vítima assediada.

O assédio moral na Administração Pública, a partir dos resultados da pesquisa, decorre do próprio trabalho de reprodução (BOURDIEU, 2014b) e naturalização dos espaços burocráticos nos quais o assediador representa o oficial, cuja manipulação simbólica do interesse público é naturalizada nas relações funcionais. Decidir sobre a lotação de servidores públicos, por exemplo, é algo inerente à rotina e dificilmente é contestada para desmascarar a presença de ação administrativa constrangedora. Urge compreendê-la não de modo isolado e inquestionável, sob o ponto de vista da discricionariedade, mas sempre inserida no caráter relacional das ações do Estado, dando voz ativa às vítimas assediadas e a rede burocrática de execução dos poderes administrativos.

É sempre relevante destacar, na linha do defendido por Bourdieu (2014b), as próprias vítimas do assédio moral constroem modos de comportamentos na Administração Pública, a partir das categorias impostas que levam a processos de depreciação ou autodesprezo sistemáticos, decorrentes de representações oriundas da visão oficial do campo, materializadas em ato administrativo (linguagem) de simples organização de escala de serviço, direcionando ações específicas à vítima assediada. Para descortinar a lógica do assédio moral nos entes públicos é preciso a atenção para a heterodoxia, considerando a própria adesão do dominado em tais contextos, a violência simbólica se institui por intermédio da adesão que o dominado não pode deixar de conceder ao dominante.

Trata-se de cuidado necessário ao examinar os casos de assédio moral. O modo do discurso oficial da Administração Pública pode, com suas classificações e categorias, ocultar relações arbitrárias de poder, a porta de entrada do assédio moral, como a sempre atuante dicotomização discricionário/vinculado e outras divisões simbólicas de exercício das competências administrativas como legítimo/ilegítimo, interesse público/interesse privado. Assim, em nome da disciplina administrativa é crível a prática do assédio, mostrando-se relevante vislumbrar tal ação social fundada nos próprios esquemas de sentido do campo 
burocrático e avaliações partilhadas pelos seus membros (BOURDIEU, 2014b). Em alguns casos, o assediador emite ordens para a vítima realizar atribuições diversas das previstas do cargo titulado. Mas qual a razão pela qual, ao menos na fase inicial, não há oposição?

A dominação ocorre em virtude da presença do caráter simbólico de assim agir e cumprir a determinação que decorre de autoridade pública e possui no seu bojo a ideia de eficiência quanto ao desempenho de atividades. Aquilo que é melhor para o serviço público, considerando o esquema dominante de "compreensão, de avaliação e de ação que são constitutivos dos habitus e que fundamentam, aquém das decisões da consciência e dos controles de vontade, uma relação de conhecimento profundamente obscura a ela mesma" (BOURDIEU, 2014b, p. 49-50). Logo, para ultrapassar tal estado de coisas, é sempre necessário indagar sobre o arbitrário administrativamente institucionalizado, transformando de modo radical as condições do campo da Administração responsáveis pela modelação dos modos de agir de dominação simbólica (BOURDIEU, 2014b).

A ideia de campo e algumas repercussões sobre a Administração Pública já foram referidas anteriormente, destacando-se a relevância do tema para pensar relacionalmente, isto é, “o que existe no mundo social são as relações" (BOURDIEU, 2008, p. 134), ultrapassando o caráter exclusivista de intersubjetividade para a análise objetiva das relações ${ }^{13}$. É possível a discussão considerando a ação do assediador com base na configuração de relações objetivas entre posições ocupadas no campo burocrático, sendo que tais posições determinam-se no âmbito dos processos de distribuição de poder (capital), cujo acesso maior ou menor influenciará no acesso a vantagens específicas que estão em jogo no campo.

Para a análise de um campo, no caso desta pesquisa, do campo da Administração Pública, são úteis as três etapas aludidas por Bourdieu (2008): a) primeiro deve-se analisar a posição do campo frente ao campo de poder, focando nos contextos relacionais em que agentes públicos inserem-se nas teias institucionais nas quais circulam diversos poderes dominantes (WACQUANT, 2015); b) em um segundo momento, "es necessário trazar un mapa de la estrutura objetiva de las relaciones entre las posiciones ocupadas por los agentes o instituciones que compiten por la forma legítima de autoridade específica del campo" (BOURDIEU, 2008, p. 143), deve-se examinar a topologia da estrutura interna do campo e suas relações de poder, supremacia, subordinação, distância, proximidade (WACQUANT, 2015) que vigoram entre os

\footnotetext{
${ }^{13}$ No entendimento do sociólogo, “[...] un campo puede ser definido como una red o una configuración de relaciones objetivas entre posiciones. Estas posiciones están objetivamente definidas, en su existencia y en las determinaciones que imponen sobre sua ocupantes, agentes o instituciones, por su situación presente y potencial (situs) en la estrutura de distribuición de espécies del poder (o capital) cuya posesión ordena el acceso a ventajas específicas que están en juego en el campo, asî como por su relación objetiva con otras posiciones (dominación, subordinación, homologia, etcétera)" (BOURDIEU, 2008, p. 134-135).
} 
agentes, na hipótese desta investigação, agentes ou instituições do campo burocrático; c) Bourdieu (2008) menciona a necessidade de examinar os diversos habitus dos agentes, os diferentes sistemas de disposições responsáveis pela prática de ações dentro do campo administrativo.

Com caráter apenas ilustrativo, retirado do universo de decisões integrantes do corpus de acórdãos proferidos pelo TJRS, destaca-se o caso retratado na Apelação Cível 70069301430, $6^{\text {a }}$ CC, julgado em 29.06.2017, no qual ficou devidamente comprovado que agente público municipal, ocupante do cargo de médico, desenvolveu ações de assédio moral, contra técnicas de enfermagem e enfermeiras do posto de saúde municipal, por meio de condutas agressivas, de humilhação e também com conotação sexual. O acórdão citado é útil para os fins desta investigação. A princípio, impõe-se compreender o assédio a partir da posição do campo administrativo dentro do campo de poder. Da análise do conteúdo da decisão de $2^{\circ}$ grau, bem como da sentença proferida pelo Juiz de Direito (Processo $\mathrm{n}^{\circ}$ 039/1.09.0000513-5), compreende-se a ingerência do Prefeito Municipal na estruturação das relações de poder na Unidade Básica do Município. Chama atenção a circunstância de as vítimas do assédio decidirem procurá-lo diretamente após diversas práticas caracterizadoras de assédio moral, com o propósito de que fossem adotadas providências administrativas. No entanto, o Prefeito municipal ameaçou exonerar as servidoras públicas assediadas, valendo-se do próprio capital funcional relacionado com a discricionariedade na prática do ato administrativo.

Os relatos e as provas produzidas durante a instrução comprovaram o modo de funcionamento do campo burocrático da Unidade Básica de Saúde no âmbito das teias de poder situadas na figura do Prefeito Municipal, ao adotar a postura de proteger o assediador, reforçando o processo de dominação frente às vítimas assediadas. Inclusive, outro aspecto revelador da ingerência do campo de poder da Administração central reside na circunstância de o Prefeito afastar, em determinado momento, a Secretaria Municipal que se solidarizou com as servidoras assediadas, conforme o relato das próprias vítimas durante a instrução do feito no $1^{\circ}$ grau de jurisdição.

Considerando a estrutura objetiva das relações internas de poder, o caso também é interessante. A defesa do Município, com o propósito de sustentar a improcedência da ação indenizatória, argumentou inexistir qualquer espécie de relação de hierarquia entre o médico e as técnicas de enfermagem e enfermeiras. A linha de argumentação, no entanto, foi rechaçada, pois a prática do assédio e as diversas descrições realizadas pelas vítimas indicaram que o médico valeu-se em diversos momentos da dependência técnica, assumindo a posição de autoridade no campo administrativo da Unidade Básica de Saúde de autoridade. A circunstância 
foi determinante para a violência simbólica desenvolvida, explicando a inicial adesão das vítimas assediadas.

O agente assediador valeu-se da posição ocupada no campo burocrático da Unidade Básica de Saúde. Na configuração das relações institucionalizadas era não apenas médico, mas o autêntico detentor de conhecimentos técnicos. Essa circunstância integrava o modo de funcionamento do órgão público, facilitando a relação de dominação, infligindo às vítimas assediadas ações vexatórias e discriminatórias, sempre permeadas pela qualidade de naturais, fruto da incorporação chefe-subordinado no desenvolvimento quotidiano. Aquilo que inicialmente parecia naturalizado, em face do aspecto simbólico de agente público protegido pela Administração Pública, impunha práticas cada vez mais humilhantes às vítimas assediadas, confirmando que o assédio moral também é resultado de acordos não conscientes entre as estruturas objetivas e as estruturas mentais (BOURDIEU, 2014a).

Em relação ao habitus dos agentes públicos no campo burocrático da Unidade Básica de Saúde, é pertinente destacar alguns aspectos das disposições do médico assediador e o entendimento da própria relação funcional com as enfermeiras e técnicas de enfermagem, vítimas assediadas, consequência do conjunto de disposições burocráticas incorporadas adquiridas ao longo das próprias condições sociais, econômicas e culturais, além da trajetória no campo da Administração Pública municipal. Os relatos contidos na decisão ora em exame são indicadores do perfil autoritário do agente assediador, primeiro em razão de considerar-se superior às enfermeiras e técnicas de enfermagem, não sob o ponto de vista da hierarquia que sequer formalmente existia, mas como agente dotado da capacidade de subjuga-las, impondo formas de trabalho nada ortodoxas, marcadas por grosserias, maus tratos e xingamentos. A título de exemplo, são impactantes as declarações sobre o dia em que o médico insultou as vítimas e rasgou cartazes feitos por elas sobre reuniões da UBS, ou então quando em outro contexto expulsou duas servidoras públicas do ônibus do Município que iria para o interior.

O exame acima realizado, apenas como exemplo, é rico para vislumbrar o modo de funcionamento do assédio moral na Administração Pública. Voltando para os resultados obtidos nos acórdãos pesquisados, para compreender o processo de violência simbólica, vale aludir de plano o dado segundo o qual das vítimas assediadas, 43,18\% eram homens e 72,7\% mulheres, e em todos os casos discutidos a prática do assédio moral ocorreu na Administração Pública Direta. O assédio praticado contra mulheres adquire a configuração de assédio sexual (FRIAS, 2020) ou assédio moral. Como ação de dominação simbólica, o assédio depende também do modo da própria organização hierárquica e das conjunturas das relações de forças. Muito embora a posição ocupada pelo assediador na estrutura burocrática, por si só, não seja 
determinante, nos acórdãos pesquisados, em 29,03\% os assediadores ocupavam cargos de diretores de escola, 19,3\% cargos de secretários municipais e 19,3\% eram servidores públicos hierarquicamente superiores em relação às vítimas assediadas, pulverizando-se os diversos cargos entre Prefeito Municipal, Delegado de Polícia, Médico, Diretor de Departamento, Coordenadora de Biblioteca, Diretor de Trânsito, aparecendo uma única vez na relação das decisões pesquisadas.

A partir da perspectiva da vítima, é importante vislumbrar a posição ocupada dentro do campo da Administração Pública, pois sofrem com as ações de violência simbólica, praticadas pelos assediadores, observando como se situam no campo. Em $25,8 \%$ dos casos, as vítimas assediadas eram professoras de escola, aparecendo ainda dentre as vítimas, mas em percentuais bem menores, 6,45\%, motoristas, agentes de trânsito, servidores contratados temporariamente, enfermeiros e operadores de máquinas. Também se registrou a presença de outros cargos públicos dentre as vítimas assediadas, como uma ocorrência registrada, dentista, assessor legislativo, escrivão de polícia, tesoureiro, agente fiscal, cozinheira de escola, diretor de escola, técnica de enfermagem, telefonista, assistente administrativo, auxiliar administrativo, vigilante, serviços gerais, servidor de secretaria de saúde e policial militar.

Mapeados, ainda que de modo breve, o habitus e o campo da Administração Pública, em casos de assédio moral judicializados, inclusive com a exemplificação no campo burocrático de unidade de saúde, nos termos propostos nesta pesquisa, é pertinente referir a presença do denominado capital funcional ou burocrático, quer dizer, o agente público assediador utiliza-se do conjunto de recursos dos quais dispõe no momento da ação para obter proveito consistente na satisfação de dominar a vítima, valendo-se de relações funcionais, acessos institucionalizados no campo burocrático, redes de contato, conhecimentos, informações, habilidades e o capital simbólico relacionado com categorias de compreensão para materializar o assédio moral. Adotando a concepção de capital simbólico, o capital funcional envolvido na prática de assédio moral na Administração relaciona-se com o modo de compreensão das relações hierárquicas e disciplinares que são impostas em determinados campos burocráticos por agentes dominantes.

Ao examinar os julgados do TJRS descobriu-se que os assediadores utilizaram em maior número o conjunto de recursos relacionados com o capital simbólico, consequência da posição dominante do assediador, para impor às vítimas ações de perseguição, isto em 48,38\% dos julgados, combinado com o dado de que dentre os poderes administrativos, o hierárquico aparece em 80,64\% dos acórdãos analisados. A disciplina na Administração Pública igualmente está imbricada com o capital simbólico, por tudo que o regime disciplinar representa e impõe 
em termos de sentidos construídos e institucionalizados, mas também, por decorrer de agente público situado hierarquicamente no patamar superior da estrutura burocrática. Há um reconhecimento imposto pelo modo de funcionamento do campo da Administração e os agentes que praticam assédio moral utilizam a condição de detentores do capital funcional. $\mathrm{O}$ assédio moral praticado com base no poder disciplinar apresentou uma ocorrência em 32,25\% nas decisões.

Tais dados são significativos e indicam que nos contextos de assédio moral há a tentativa do assediador de valer-se de uma ordem legitimada pelo capital simbólico (funcional) do qual é detentor. E não que as vítimas assediadas, igualmente integrantes do campo administrativo, sejam despidas, dependendo do caso, de alguma espécie de capital funcional, mas, dentro do mercado burocrático de poder, a distribuição é desigual. Os agentes assediadores - dominantes - são responsáveis por aplicar às estruturas objetivas da administração, modos de percepção e que para as vítimas assediadas tornam evidentes aquele modo de funcionamento, ao menos nos estágios iniciais da ação assediadora.

A título de referência, podem ser mencionados alguns modos de praticar o assédio moral nos quais os agentes públicos fundaram suas ações ilegítimas na própria condição de reconhecimento da posição ocupada no campo, apresentando-se como a autoridade administrativa com a prerrogativa de reverter turnos de trabalho, remover servidores, exonerar, elaborar escalas de serviço, realizar cobranças quanto à produtividade e proibir os servidores de realizar atividades no ambiente funcional. Em tais casos, o assediador praticou o assédio moral reproduzindo as relações de força do campo burocrático, constituindo o próprio modo de estrutura do espaço administrativo, subjugando a vítima, atendendo as necessidades do modo perverso de compreensão das relações funcionais.

Ao valer-se, da prerrogativa pública de remoção ou então do poder de exonerar agente público, o assediador, detentor de capital simbólico, por meio do qual exerce seu poder, aproveita-se do que Bourdieu (2004, p. 164) refere como nominação oficial, "o ato pelo qual se outorga a alguém um título, uma qualificação socialmente reconhecida, é uma das manifestações mais típicas do monopólio da violência simbólica legítima, monopólio que pertence ao Estado ou aos seus mandatários". Assim, ao agente que pratica o assédio incumbe qualificar a vítima assediada como mau servidor público, incompetente, criador de caso, ou qualquer outra nominação oficial capaz de justificar a utilização da prerrogativa pública. 


\section{Conclusão}

O Assédio Moral na Administração Pública não é um fenômeno novo, apenas faltava melhor nominá-lo como prática ilegítima do exercício das competências administrativas. Tratase de ação administrativa relacionada com processos de dominação do agente assediador sobre a vítima assediada. $\mathrm{O}$ espaço burocrático, muito embora constituído como atividade ordenada por regulamentos, por leis ou normas administrativas e fundado no princípio da autoridade, como referiu Max Weber, configura-se ambiente propício para o assédio moral.

A Administração Pública precisa evoluir muito em termos de institucionalização de mecanismos preventivos. Em que pese primar pelo tratamento isonômico, a bandeira da impessoalidade produziu alguns efeitos colaterais, dentre eles, a incapacidade do setor burocrático para compreender as ações e omissões praticadas por agentes assediadores na vida quotidiana do serviço público.

A caracterização do assédio moral na Administração Pública exige o permanente diálogo com outras normatividades. Não se trata de noção que surgiu no âmbito do Direito Administrativo, mas relacionada com tratamento vexatório, humilhação, perseguição imposição de castigos e tantas outras condutas utilizadas para materializar a submissão. $\mathrm{O}$ estudo aqui desenvolvido vai além das normatividades, adotou o olhar sociológico, compreendendo tal prática como ação sociojurídica, resultado do habitus do agente público assediador, ou seja, um conjunto de disposições, do modo de agir no espaço administrativo com indiferença e adotando condutas de dominação, discriminatórias, marcadas por humilhações e abusividades.

Durante o trabalho de pesquisa da jurisprudência do Tribunal de Justiça do Estado do Rio Grande do Sul e das Turmas Recursais da Fazenda Pública destacaram-se alguns indicadores importantes para configurar o assédio moral na Administração Pública como espécie de violência simbólica. A discricionariedade administrativa é um deles, configurandose por meio de ações burocráticas de ordenar e designar para a realização de tarefas, mas de modo a esvaziar as atribuições da vítima assediada. Também o sentido de interesse público foi utilizado em diversos casos, explicando a inicial submissão do servidor assediado, considerando não a força física da ação, mas a dimensão simbólica, impondo estruturas cognitivas sobre o sentido de interesse público. A conduta praticada por assediadores conta com a presunção de legitimidade do discurso oficial, o dizer burocrático capaz de institucionalizar uma versão do modo de funcionamento do campo administrativo. 
Conforme aludido, com o propósito de ultrapassar algumas concepções subjetivistas do assédio moral, é relevante situar tal ação no horizonte do campo burocrático, vislumbrado como espaço estruturado de posições, postos, no caso da Administração Pública, cargos, cujas propriedades dependem das posições dos agentes nestes espaços, dotados de algumas leis de caráter geral em relação ao cotidiano do fazer burocrático.

Referiu-se, por fim, a necessidade de compreender o conjunto de capitais envolvidos, incorporados no que se denominou de capital funcional, assemelhando-se ao capital simbólico, agregando as dimensões do capital econômico, do capital cultural e do capital social, indicando a perversidade envolvida no assédio moral.

A análise jurisprudencial realizada, dialogando com as indicações sociológicas habitus, campo e capital, comprovou que muitos dos casos julgados originaram-se do próprio modo de construção dos espaços de poder da Administração, cujo exercício de competências administrativas reforçou a ideia de subjugar a vítima assediada. Outro dado digno de nota reside na circunstância de o assédio relacionar-se com o campo de poder, no qual o campo administrativo insere-se. No acórdão analisado a título exemplificativo, a ação do assediador iniciou e perdurou no tempo em virtude da proteção oriunda do chefe do Poder Executivo, reforçando o processo de dominação direcionado para as vítimas.

Investigar o assédio moral no âmbito do campo administrativo do Estado é útil para entender o seu modo de funcionamento como ação sociológica de caráter relacional, bem como desenvolver algumas estratégias eficazes para a prevenção.

De plano, urge aprofundar a democratização dos espaços administrativos, tornando as relações funcionais entre os agentes menos arbitrárias. É preciso reconfigurar o exercício da hierarquia, laborando preventivamente de modo a conscientizar sobre a necessidade do uso legítimo de tal prerrogativa de organização, impedindo o desenvolvimento de processos de dominação.

Criar ambientes de maior diálogo e transparência ajuda no sentido de compreender a hierarquia como algo para o bom funcionamento do campo da Administração. Igual trabalho deve ser feito no que tange ao poder disciplinar. Disciplina não pode confundir-se com arbítrio, cabendo ao ente público construir mecanismos capazes de identificar a prática do assédio em situações rotineiras de instauração de processos administrativos disciplinares. $\mathrm{O}$ caráter preventivo materializa-se com a adoção do sistema de controle interno, filtrando decisões administrativas disciplinares, o que exige qualificação de agentes públicos sobre assédio moral.

Outro aspecto relevante consiste na desconstrução do aspecto simbólico relacionado com a discricionariedade administrativa, ultrapassando-se a doxa dominante atribuindo ao 
agente público parcela considerável de poder e controles despreparados para detectarem a ocorrência de ações administrativas abusivas. O diálogo e a conscientização dos integrantes do campo burocrático e o permanente debate sobre assédio moral são mecanismos para o funcionamento diverso do espaço do Estado, com maior respeito e primando pelo paradigma do cuidado.

A concepção dialógica de administrar máquina pública deve contar com comissões paritárias, nas quais servidores, autoridades e integrantes de sindicatos, discutam sobre a melhor distribuição dos poderes administrativos e os meios necessários para desenvolver ações direcionadas para o reconhecimento dos agentes públicos em quadros de vulnerabilidade ocasionados por assédio moral.

\section{Referências}

ARENAS, Marlene Valério dos Santos. Assédio Moral e Saúde no Trabalho do Servidor Público do Judiciário: implicações psicossociais. Tese de Doutorado. Porto Alegre: Universidade Federal do Rio Grande do Sul - UFRGS, 2013.

BINENBOJM, Gustavo. Uma Teoria do Direito Administrativo. Direitos Fundamentais, Democracia e Constitucionalização. 3. ed. Rio de Janeiro: Renovar, 2014.

BATISTA, Vera. Assédio: queixas aumentam, mas processos diminuem. Correio Brasiliense. 06/05/2019. Disponível em: https://www.correiobraziliense.com.br/ app/noticia/brasil/2019/05/06/interna-brasil,753261/casos-de-assedio-moral-crescem-nobrasil.shtml. Acesso em: 04 jun. 2020.

BOURDIEU, Pierre. Questões de Sociologia. Rio de Janeiro: Editora Marco Zero Limitada, 1983.

BOURDIEU, Pierre. O Poder Simbólico. Tradução de Fernando Tomaz. Rio de Janeiro: Difel/Bertrand, 1989.

BOURDIEU, Pierre. Esboço de uma Teoria da Prática. In: Sociologia. 2. ed. Organizador Renato Ortiz. São Paulo: Ática, 1994.

BOURDIEU, Pierre. A Economia das Trocas Linguísticas. Tradução Sérgio Miceli. São Paulo: EDUSP, 1996.

BOURDIEU, Pierre. Meditações Pascalianas. Rio de Janeiro: Bertrand Brasil, 2001a.

BOURDIEU, Pierre. Coisas Ditas. Tradução Cássia R. da Silveira e Denise Moreno Pegorim. São Paulo: Brasiliense, 2004.

BOURDIEU, Pierre; WACQUANT, Loïc. Una Invitación a la Sociologia Reflexiva. Buenos Aires: Siglo XXI Editores, 2008. 
BOURDIEU, Pierre. Sobre o Estado. Cursos no Collège de France (1989-92). Tradução Rosa Freire d'Aguir. São Paulo. Cia. das Letras, 2014a.

BOURDIEU, Pierre. A Dominação Masculina. 12. ed. Rio de Janeiro: Bertrand, 2014b.

CASSAGNE, Juan Carlos. El Principio de Legalidad y el Control Judicial de la

Discricionalidad Administrativa. 2. ed. Buenos Aires: Editorial B de F, 2016.

COGLIANDRO, Antonio. Il Mobbing nella pubblica amministrazione aspetti: social, psicologici e giuridici anche ala luce della recente sentenza della Cassazione n. 10037/2015.

COSTA, José Armando da. Direito Disciplinar. Temas Substantivos e Processuais. Belo Horizonte: Editora Fórum, 2008.

DI PIETRO, Maria Sylvia Zanella. Discricionariedade Administrativa na Constituição de 1988. 2. ed. São Paulo: Atlas, 2001.

FREITAS, Juarez. O Controle dos Atos Administrativos e os Princípios Fundamentais. 5 ed. São Paulo: Malheiros, 2013.

FRIAS, Sonia M. Hostigamiento y Acoso Sexual. El caso de una instituición de procuración de justicia. Estudios Sociológicos. México, v. 38, n.112, p. 103-139, enero-abril. 2020.

FURLAN, Paulo Eduardo Meneghetti; ALMEIDA, Victor Hugo. Legitimidade e Mecanismos de Proteção do Trabalhador em Situações de Assédio Moral: uma perspectiva laboralambiental. Revista Thesis Juris - RTJ, São Paulo, v. 6, n. 1, p.101-119, jan./abr.2017.

GIDDENS, Anthony. Sociologia. Tradução: Ronaldo Cataldo. Costa; revisão técnica: Fernando Coutinho Cotanda. 6. ed. Porto Alegre: Penso, 2012.

GÓMEZ JIMÉNEZ, Esther. El Accoso en la Administración Pública. Una Propuesta de Intervención a través de la mediación. Lan Harremanak, Revista de Relaciones Laborales. Universidad del Pais Vasco, 36 (2017-I) (247-263).

HIRIGOYEN, Marie-France. Assédio Moral. A Violência Perversa do Cotidiano. Tradução de Maria Helena Kühner. 15. ed. Rio de Janeiro: Bertrand Brasil, 2014.

JOURDAIN, Anne e NAULIN, Sidonie. A Teoria de Pierre Bourdieu e seus Usos Sociológicos. Tradução de Francisco Morás. Petrópolis, RJ: Vozes, 2017.

LIMA, Ruy Cirne. Princípios de Direito Administrativo. 7. ed. Revista e Reelaborada por Paulo Alberto Pasqualini. São Paulo: Malheiros, 2007.

LIMA, Denise Maria de Oliveira. Campo do Poder, Segundo Pierre Bourdieu. In: Cógito, Salvador, n. 11, Outubro, 2010.

LORENZO DE MEMBIELA, Juan B. Mobbing en la Administración. Reflexiones sobre la Dominación Burocrática. Barcelona: Bosch Editor, 2007. 
MERTON, Robert. Sociologia: Teoria e Estrutura. Tradução de Miguel Maillet. São Paulo: Mestre Jou, 1970.

NASCIMENTO, Sônia Aparecida Costa Mascaro. Assédio moral no ambiente do trabalho. Revista LTr, São Paulo: LTr, 2004.

NOHARA, Irene Patrícia. Reforma Administrativa e Burocracia: impacto da eficiência na configuração do Direito Administrativo Brasileiro. São Paulo: Atlas, 2012.

OLIVEIRA, Rafael Carvalho Rezende. Organização Administrativa. 4. ed. Rio de Janeiro: Forense; São Paulo: Método, 2018.

REDINHA, Maria Regina Gomes. Assédio Moral ou Mobbing no Trabalho. Separata de Estudos em Homenagem ao Prof. Doutor Raúl Ventura. Lisboa: Edição da Faculdade de Direito da Universidade de Lisboa, 2003.

SÁNCHEZ MORÓN, Miguel. Derecho de la Función Pública. 5. ed. Madrid: Tecnos, 2008.

SANTOS, Francisco Geraldo M. O Campo Jurídico e a Formação do Estado Moderno à Luz da Teoria Sociológica de Pierre Bourdieu. RBSD - Revista Brasileira de Sociologia do Direito, v. 7, n.1, p. 18-32, jan./abr. 2020.

THIRY-CHERQUES, Hermano Roberto. Pierre Bourdieu: a teoria na prática. Revista Administração Pública (online), vol. 40, n. 1, p. 27-53, 2006.

TORRES, Marcelo Douglas de Figueiredo, Estado, Democracia e Administração Pública no Brasil. Rio de Janeiro: FGV, 2004.

TEMÓTEO, Antonio. Um processo por assédio moral é registrado a cada 55 horas. Correio Brasiliense. 23/10/2016. Disponível em: https://www.correiobraziliense.com.br/ app/noticia/economia/2016/10/23/internas_economia,554349/um-processo-por-assediomoral-e-registrado-a-cada-55-horas.shtml. Acesso em: 04 jun. 2020.

WACQUANT, Löic. Esclarecer o Habitus. In: Educação e Linguagem. Ano 10. nº 16, jul.dez., 2007.

WACQUANT, Loïc. Mapear o Campo Artístico, p. 117. In: Sociologia, Problemas e Práticas, n. 48, 2015, Portugal.

WEBER, Max. Burocracia. In: Ensaios de Sociologia. 5. ed. Tradução Waltensir Dutra. Rio de Janeiro: LTC, 1982, p. 229-282. 